\title{
More than just a Propagandist for Tea: Religious Argument and Advice on a Healthy Life in the Work of the Dutch Physician Cornelis Bontekoe (1647-1685)
}

\author{
CHRISTOPH SCHWEIKARDT ${ }^{*}$
}

\section{Introduction}

The Dutch physician Cornelis Bontekoe was a well-known and controversial figure, ${ }^{1}$ best remembered as a propagandist for tea. ${ }^{2}$ His popular Tractaat van het excellenste kruyd thee (Treatise on Tea, the Most Excellent Herb), commonly known as Theetractaat (The Tea Treatise), was printed in 1678, and two more editions appeared in 1679 and $1685 .^{3}$ Allegedly, he was remunerated by the Dutch United East India Company, which imported tea in large quantities from China. ${ }^{4}$ Although Bontekoe preferred a small number of

\footnotetext{
* Dr Christoph Schweikardt, Abteilung für Geschichte der Medizin, Medizinische Fakultät, Ruhr-Universität Bochum, Malakowturm, Markstrasse 258a, D-44799 Bochum, Germany.
}

This article is a revised version of a manuscript based on two lectures, the first at the Conference 'The Healthy Life' of the European Association for the History of Medicine and Health, Almuñecar, Spain, 2-5 September 1999, with the title " De Gesondheit is de feliciteyt van dit leven ...": health and its preservation in the work of the Dutch Physician Cornelis Bontekoe (1647-1685)', and the second at the 'Werkgezelschap Antieke Geneeskunde' with the title 'Ten strijde tegen de galenische behandelwijzen: Opvattingen van de Nederlandse arts Cornelis Bontekoe (1647-1685) tegen de achtergrond van de 17de-eeuwse geneeskunde' held in Leiden, the Netherlands, on 31 March 2000. The written version of the latter lecture is published in the Dutch journal Geschiedenis der Geneeskunde 20002001, 7: 228-35. I wish to express my gratitude to Prof. Dr Johannes van den Berg, Prof. Dr Harm Beukers, Prof. Harold Cook, Dr Manfred Horstmanshoff, Dr Frank Huisman, Prof. Vivian Nutton, Dr Wim Verboom and Dr Rienk Vermij for their comments as well as Susanne Schulze-Jaschok for her help with the translation into English.

\footnotetext{
${ }^{1}$ On Bontekoe, see Johann Heinrich Zedler, Grosses vollständiges Universal-Lexikon, 64 vols, Halle and Leipzig, Johann Heinrich Zedler, 1733-54, vol. 4, Reprint, Graz, Akademische Druck- u. Verlagsanstalt, 1961, col. 683-4; Jelle Banga,
}

Geschiedenis van de geneeskunde en van hare beoefenaren in Nederland, Leeuwarden, Eekhoff, 1868, Facsimile herdruk met een inleiding door Prof. Dr G A Lindeboom, Schiedam, Interbook International, 1975, pp. 627-36; C Louise Thijssen-Schoute,

Nederlands cartesianisme, Amsterdam, NoordHollandsche Uitgevers Maatschappij, 1954, pp. 276$318,322-7$, especially her criticism on Evert Dirk Baumann, Cornelis Bontekoe (1640 [sic]-1685), de Theedoctor, Oosterbeek, Karel F Misset, 1949. A large part of the Dutch historiography is lacking in Jürgen Splett, 'Bontekoe (eigentl. Decker), Cornelius', in Lothar Noack and Jürgen Splett, Bio-Bibliographien: Brandenburgische Gelehrte der frühen Neuzeit, Berlin, Akademie Verlag, 1997, pp. 65-72.

${ }^{2}$ For Bontekoe's belief in the positive effects of tea, see Edith Heischkel-Artelt, 'Kaffee und Tee im Spiegel der medizinischen Literatur des 17. bis 19.

Jahrhunderts', in Medizinhistorisches Journal, 1969, 4: 250-60, pp. 252-3; and Baumann, op. cit., note 1 above, pp. 111-14. For the spread of tea, see Rudi Matthee, 'Exotic substances: the introduction and global spread of tobacco, coffee, cocoa, tea, and distilled liquor, sixteenth to eighteenth centuries', in Roy Porter, Mikulás Teich (eds), Drugs and narcotics in history, Cambridge University Press, 1995, pp. 24-51.

${ }^{3}$ Baumann, op. cit., note 1 above, p. 25 . As for Bontekoe's popular book on tea, the second edition of 1679 is used in this paper: Cornelis Bontekoe, Tractaat van het excellenste kruyd thee, 's-Gravenhage, Pieter Hagen, 1679.

${ }^{4}$ Evert Dirk Baumann, De dokter en de geneeskunde, part 2, De wetenschap, Amsterdam, H Meulenhoff, 1915, p. 84. 


\section{Christoph Schweikardt}

well tried, reliable drugs, ${ }^{5}$ the Theetractaat gave the impression that tea was a panacea, and was criticized for this. ${ }^{6}$ However, the treatise offers more than just praise for the beneficial effects of tea. It contains medical as well as religious and moral advice for a long and healthy life. Bontekoe's book is an important source, much more than simply a textbook. Digressions and polemical attacks give additional insights into the author's thinking. In the words of Bontekoe himself, the book was "rather fallen from the pen than considered", and it explicitly unites medicine and morality. ${ }^{7}$ In 'Van de middelen, om het leven en de gesondheid lang te bewaren' (Ways to Maintain Life and Health for a long Time), ${ }^{8}$ in his collected writings, religious arguments also play an important role. The same goes for his Gebruik en mis-bruik van de thee (Use and Misuse of Tea), posthumously edited by his colleague Steven Blankaart (1650-1702). ${ }^{9}$

Bontekoe's religious views have been underestimated or disregarded so far in works on his life and career, his fight for Cartesian ideas ${ }^{10}$ and against Galenist therapy, his heart physiology, ${ }^{11}$ his pathology as shown in his tract on fevers, ${ }^{12}$ and the bio-bibliography of Jürgen Splett. The monograph by Evert Dirk Baumann only mentions his religious views in general. So this study of Bontekoe seeks to contribute to the lively international debate on the relationship between religion and medicine in early modern Europe. Ole Peter Grell and Andrew Cunningham have emphasized the deeply religious nature of attitudes to diseases and their causes and cures held by physicians and patients in England. ${ }^{13}$ Peter Elmer has challenged the Puritan contribution to medical science ${ }^{14}$ taking issue with Charles Webster's The great instauration ${ }^{15}$ over the movement for medical reform. Among scholars writing on the Netherlands, Mart van Lieburg has examined the impact of religion on

\footnotetext{
${ }^{5}$ Bontekoe mentions eight special remedies, among these opium and antimony. Cornelis Bontekoe, 'Van de middelen, om het leven en de gesondheid lang te bewaren', in idem, Alle de philosophische, medicinale en chymische werken van den heer Corn. Bontekoe, 2 vols, Amsterdam, Jan ten Hoorn, 1689, vol. 2, pp. 199276 , on p. 241.

${ }^{6}$ Albrecht von Haller, Bibliotheca medicinae practicae, vol. 3, Ab anno 1648. Ad a. 1685, Bern, Em. Haller, and Basel, Joh. Schweighauser, 1779, Reprint, Hildesheim, Olms, 1986, p. 425. Septimus Podagra, Der profitable Apothecker-Tod in dem frembden Kräutlein Thee, samt seiner Medicinischen Sackpfeife, n.p., 1721.

${ }^{7}$ Bontekoe, second preface, 'Een

waarschouwinge', in idem, op. cit., note 3 above, unpaginated.

${ }^{8}$ Bontekoe, 'Van de middelen', in Alle de philosophische ... werken, op. cit., note 5 above, vol. 2.

${ }^{9}$ Cornelis Bontekoe, Gebruik en mis-bruik van de thee, mitsgaders een verhandelinge wegens de deugden en kragten van de tabak. Door Cornelis Bontekoe. Hier nevens een verhandelinge van de coffee, met des zelfs krachten in gezonde, en ongezonde. Door Stephanus Blankaart, 's-Gravenhage, Pieter Hagen, and Amsterdam, Jan ten Hoorn, 1686.

${ }^{10}$ Thijssen-Schoute, op. cit., note 1 above; for an overview on Cartesian philosophy in the Netherlands, see Paul Dibon, 'Der Cartesianismus in den
}

Niederlanden', in Jean-Pierre Schobinger (ed.), Die Philosophie des 17. Jahrhunderts, vol. 2, Frankreich und Niederlande, Basel, Schwabe, 1993, pp. 349-74, on the conflict in Leiden, where Bontekoe participated, p. 372 .

${ }^{11}$ Thomas Fuchs, Die Mechanisierung des Herzens: Harvey und Descartes, der vitale und der mechanische Aspekt des Kreislaufs, Frankfurt am Main, Suhrkamp, 1992, pp. 158-60.

12 Johanna Geyer-Kordesch, 'Fever and other fundamentals: Dutch and German medical explanations c. 1680 to 1730 ', in W F Bynum and $\mathrm{V}$ Nutton (eds), Theories of fever from Antiquity to the Enlightenment, Medical History, Supplement No. 1, London, Wellcome Institute for the History of Medicine, 1981, pp. 99-120.

${ }^{13}$ Ole Peter Grell and Andrew Cunningham, 'Introduction: medicine and religion in seventeenthcentury England', in idem (eds), Religio medici: medicine and religion in seventeenth-century England, Aldershot, Scolar Press, 1996, pp. 1-11, on p. 1.

${ }^{14}$ Peter Elmer, 'Medicine, religion and the puritan revolution', in Roger French and Andrew Wear (eds), The medical revolution of the seventeenth century, Cambridge University Press, 1989, pp. 10-45.

${ }^{15}$ Charles Webster, The great instauration: science, medicine and reform 1626-1660, London, Duckworth, 1975. 


\section{More than just a Propagandist for Tea}

medical practice, based on the analysis of Pietist writings and the minutes of the Reformed Churches of Rotterdam. He points to the difficulty of integrating the new discoveries in human anatomy and physiology with the concepts of theology and theological anthropology in the later seventeenth century. ${ }^{16}$ Roger French has discussed the success of Harvey's blood circulation theory in the Netherlands of the seventeenth-century and emphasized the importance of the religious context for an understanding of physicians and scientists in the Dutch Golden Age. ${ }^{17}$ Harold Cook's monograph on Bontekoe's contemporary, the physician Joannes Groenevelt (1648-1716), looks at his religious upbringing and discusses the religious currents of the time, before taking up the role of the Royal College of Physicians in London after Groenevelt's emigration to England. Recently, Cook has also studied the views of the famous physician and Leiden medical professor Herman Boerhaave (16681738), who rejected doctrine in favour of experience. ${ }^{18}$ Furthermore, the handbook $A$ history of science in the Netherlands provides us with Rienk Vermij's general survey of science and belief in Dutch history. ${ }^{19}$

In this paper, I am going to show Bontekoe's position within the main religious currents in the Netherlands at the time, the significance of his religious attitudes for deciding truth, his fight for proper medicine and the individual's duty to care for his or her health. Then, I briefly look at his career and the conflicts with his colleagues. Finally, I question whether his attitude and his religious views support Johanna Geyer-Kordesch's portrayal of him as an Enlightenment medical reformer.

\section{Bontekoe's Intellectual Orientation}

During the revolt of the Dutch against the Spaniards, the Calvinists were one of the driving forces of resistance. ${ }^{20}$ They supported the regents of the towns of Holland, who gave them freedom of worship and then turned their church into the only officially acknowledged church of the United Provinces. ${ }^{21}$ At the Synod of Dordrecht (Dordt) in 1619 the followers of Jacobus Arminius (1560-1609), who opposed the strict Calvinist version of the doctrine of predestination, were condemned, and the Dutch Reformed Church was established as an orthodox institution. Discussions of science and belief in the Netherlands in the seventeenth century centred almost exclusively around Cartesian philosophy, which gained influence in the 1640s. Within the Reformed Church, Gisbertus Voetius (1589-1676), professor of theology at Utrecht University, defended neoscholasticism and Aristotelian philosophy. He and his followers fought Cartesianism together with Copernicanism, the notion that the earth moved around the sun.

\footnotetext{
${ }^{16}$ Mart van Lieburg, 'Religion and medical practice in the Netherlands in the seventeenth century: an introduction', in Hilary Marland and Margaret Pelling (eds), The task of healing: medicine, religion, and gender in England and the Netherlands 1450-1800, Rotterdam, Erasmus Publishing, 1996, pp. 135-43, p. 137.

${ }^{17}$ Roger French, 'Harvey in Holland: circulation and the Calvinists', in French and Wear (eds), op. cit., note 14 above, pp. 46-86.

${ }^{18}$ Harold Cook, 'Boerhaave and the flight from reason in medicine', Bull. Hist.Med., 2000, 74: 221-40, on p. 225.
} 


\section{Christoph Schweikardt}

Many people, highly critical of Aristotelian philosophy, welcomed Cartesian ideas, which had affinities with the school of thought of Johannes Coccejus (1603-69), who was not a philosopher himself, but a professor of theology at Leiden University. Some of his followers were accused of Cartesian sympathies. During the remainder of the century, Cocceian and Voetian theologians continued to dispute the movement or immobility of the earth and other points of Cartesian interpretation of nature.

Bontekoe's 'Apology' at the end of the Theetractaat in the 1679 edition gives a hint of his view on Copernicanism, namely that he accepted it in the Cartesian interpretation. It shows him as a supporter of Descartes within the Cocceian camp. Bontekoe defended the Reformed Church and some of its fundamental positions such as opposition to the Roman Catholic Church and the condemnation of Spinoza. He denounced the beliefs of the Arminians and the Mennonites as not founded in the true religion and lacking reason. ${ }^{22}$ He also strongly refuted the accusation that he was an atheist, ${ }^{23}$ portraying himself as a fighter for truth and a follower of God's word whose motivation was Christian love. ${ }^{24}$

On the title-page of his collected writings there appears the Latin aphorism which was Bontekoe's motto: “VIGET, VIGEBIT, VICTA VINCET VERITAS”. Bontekoe translated-and interpreted-this as follows:

The TRUTH stands like an unmoved rock

Fast against the surge of the waves,

The time which follows shall make her visible in the darkness

Like a fire beacon

And although she shipwrecked went down

Like getting drowned

She climbs up again and shall stay drifting above And so remain IMMORTAL. ${ }^{25}$

According to Bontekoe, the truth was based on both Christian knowledge and knowledge of nature. Truth must be pursued without regard for the consequences; its followers should be prepared to be hated and persecuted and to give up all hope of wealth and honour. ${ }^{26}$ Bontekoe's religious zeal took Luther and Calvin as its models. He would fight for true medicine as they had fought for the true religion against the false religion of Rome. He compared the medicine of his Galenist colleagues at The Hague with the erroneous teaching of the Catholic Church. ${ }^{27}$ Galen was the arch-enemy, representing old medicine, whereas Hippocrates was honoured as the "Oudvader" and "Heathen master". ${ }^{28}$ Bontekoe's

\footnotetext{
${ }^{22}$ Bontekoe, Tractaat, op. cit., note 3 above, pp. $329,360,348,349,351$.

${ }^{23}$ Ibid., p. 349 . On the problem of "atheism" in seventeenth-century Netherlands, see Rienk Hendrik Vermij, Secularisering en natuurwetenschap in de zeventiende en achttiende eeuw: Bernard Nieuwentijt, Amsterdam, Rodopi, 1991, pp. 56-8.

${ }^{24}$ Bontekoe, Tractaat, op. cit., note 3 above, pp. 322, 328-30.

${ }^{25}$ 'Den uitgeever tot den lezer', in Bontekoe, Alle de philosophische ... werken, op. cit., note 5 above, vol. 2, unpaginated: "De WAARHEID staat gelyk een onbeweegde rots / Vast tegen 't baar gebots, I De tyd, die volgt, zal haar in 't duister kenbaar
}

maaken, / Gelyk een vuur'ge baken. / En schoon ze schipbreuk lydende, ten afgrond ging, / Gelyk een dronkeling; / Zy klimt weer op, en zal behouden boven dryven, / En zo ONSTERFLYK blyven".

${ }^{26}$ Bontekoe, Tractaat, op. cit., note 3 above, pp. 354, 325; Bontekoe, 'Voor-reden des autheurs aan den lezer', in Alle de philosophische ... werken, op. cit., note 5 above, vol. 1, unpaginated.

${ }^{27}$ Bontekoe, Tractaat, op. cit., note 3 above, pp. 327, 346.

${ }^{28}$ Bontekoe, 'Voor-reden des autheurs aan den lezer', in Alle de philosophische ... werken, op. cit., note 5 above, vol. 1 , unpaginated. 
Gebruik en mis-bruik van de thee stated that Galen, an enemy of Hippocrates and of all Christians, filled his books with deadly remedies. ${ }^{29}$ Blind followers of Galen, who supported his views without research and stuck to the "old order", mistreated the sick and acted incompetently. Tormentors and even murderers, they were doctors in name only. ${ }^{30}$

With the help of the discoveries of the seventeenth century, the Galenist medical system would be destroyed. The subtitle of Bontekoe's collected writings reveals his intention to overthrow the old system of medicine, surgery and pharmacy, and to build a new philosophy, medicine and chemistry. ${ }^{31}$ The foundation of this would be the root of all science (wetenschappen), the true philosophy, Cartesianism. Anatomy and chemistry were compared with the atlas of medicine and surgery. ${ }^{32}$ According to this, true anatomy included Harvey's discovery of blood circulation. ${ }^{33}$ Disagreeing with his predecessors Descartes ${ }^{34}$ and Sylvius ${ }^{35}$ on medical details, Bontekoe recognized that medicine was still imperfect and that further experimentation was necessary. ${ }^{36} \mathrm{He}$ also explained the close relationship between religion and medicine, between sin and disease, in his advice for a long and healthy life, and in the debate on procreation.

The explanation for disease, pain and death, Bontekoe maintained, was that all diseases and even death itself were the result of human sin. He strongly rejected the notion that death was a natural consequence of human life. The widely used comparison of a human being with a tree, which grows old in time and is no longer able to bear fruit and leaves, was wrong and very dangerous. He argued on strict theological lines, starting with an explanation of the relationship between the soul and the body and the fall of man. The soul is immortal. ${ }^{37}$ Human life consists in the union of soul and body. The body is sinful, pulls the soul to himself, unites himself with her and holds her back from union with God. In a state of health, the body is the servant of the soul; in disease, its tyrant, tormentor and prison. ${ }^{38}$ Adam would have lived eternally had it not been for the Fall. As a result of this, however, Adam and his descendants lost their knowledge of how to maintain health through right living. Air and earth are cursed. They attempt to make the lives of humans miserable and kill them. Human beings are set at odds with each other. ${ }^{39}$

\footnotetext{
${ }^{29}$ Bontekoe, Gebruik en mis-bruik, op. cit., note 9 above, p. 40.

${ }^{30}$ Bontekoe, Tractaat, op. cit., note 3 above, pp. 326, 327, 342, 347.

${ }^{31}$ Bontekoe, Alle de philosophische ... werken, op. cit., note 5 above; the sub-title is: Behelsende een afwerp der ongefondeerte medicyne, chirurgie en pharmacie der oude genees-heeren, neffens den opbouw van een ware philosophie, medicyne en chymie, dienende om de gesondheid lang te bewaren, en de siektens kort en veilig te genesen.

${ }^{32}$ Bontekoe, 'Voor-reden des autheurs aan den lezer', in Alle de philosophische ... werken, op. cit., note 5 above, vol. 1 , unpaginated.

${ }^{33}$ Bontekoe, Tractaat, op. cit., note 3 above, pp. 322-3.

${ }^{34}$ Bontekoe disagreed with Descartes on, for example, the role of the pineal gland: Bontekoe, 'Voorreden des autheurs aan den lezer', in Alle de philosophische ... werken, op. cit., note 5 above, vol. 1 ,
}

unpaginated; Bontekoe, 'Van de ledematen des lichaams', in ibid., vol. 2, pp. 74-138, on pp. 130-1.

${ }^{35}$ Bontekoe, 'Reden over de koortsen', in Alle de philosophische ... werken, op. cit., note 5 above, vol. 2 , pp. 291-340, on pp. 315-16. Here, Bontekoe regards Sylvius as a second Hippocrates and criticizes him in details. Fuchs, op. cit., note 11 above, pp. 154-6, 15860 , describes Sylvius' and Bontekoe's views on the function of the heart.

${ }^{36}$ Bontekoe, "Voor-reden des autheurs aan den lezer', in Alle de philosophische ... werken, op. cit., note 5 above, vol. 1, unpaginated.

${ }^{37}$ Bontekoe, Tractaat, op. cit., note 3 above, pp. 3 , 4, 42. Castigation is not entirely excluded, see pp. 45-6.

${ }_{38}$ Bontekoe, Tractaat, op. cit., note 3 above, p. 63. For the more complicated philosophical elaboration, see Thijssen-Schoute, op. cit., note 1 above, pp. 298-9.

${ }^{39}$ Bontekoe, Tractaat, op. cit., note 3 above, pp. 6 , 7, 42-3. 


\section{Christoph Schweikardt}

Taking the Bible literally, Bontekoe maintained that Adam had lived 930 years ${ }^{40}$ but in the course of time his descendants had reduced their life span to less than 100 years because they had increasingly succumbed to sin and depravity. ${ }^{41}$ Bontekoe strongly denied that man was subject to disease, pain and death by nature. If disease, pain and death were not the result of man's sin, God would be the source of evil. He would torment his creatures although they did not deserve such strict punishment. ${ }^{42}$ Bontekoe acknowledged that God used disease to castigate his children, ${ }^{43}$ but its prime cause was human iniquity. A person acted badly because he wanted to, because his will was the slave of sin, given over to lust and pleasure. ${ }^{44}$ Bontekoe provided examples of the consequences of such behaviour. A woman who displayed her bare breasts decorated with jewels, might contract breast cancer as a punishment. The idea of punishment was combined with a physiological explanation: coldness is harmful to life; the bare breasts will cool down and so contract cancer. ${ }^{45}$ Another example is the death of a child before birth. Either the child itself or the mother is guilty of sin. The child could have misused his strength to strangle himself or commit suicide in some other way. The mother could have killed her child either by uncontrolled passion-fright, anger, quarrelling - or by falling, taking the wrong exercise such as dancing, eating the wrong food, accepting bloodletting or other harmful therapies. Health is a great treasure, given by God, and the duty to care for one's health, and thus prolong life, is important, second only to that of caring for the soul. Although health is the source of a good life, most people do not live as if this were the case. Bontekoe was astonished that neither the ministers of his church nor other Christians reflected on God's orders to lead a healthy life. ${ }^{46}$ So he devoted himself to this task.

Both the Theetractaat, and the 'Van de middelen' deal with how to lead a healthy life. Although Bontekoe rejected Galenism, his statements clearly show that he was influenced by the Galenist tradition. Since antiquity, the "sex res non naturales", the "six nonnaturals", had been an important part of hygiene. They had been used by the physicians of the well-to-do in order to teach their clients the benefits of a healthy lifestyle,${ }^{47}$ and were included in early modern vernacular regimens and medical advice books. Written for the lay person in the vernacular, they were accessible to anyone who could read. ${ }^{48}$ The "nonnaturals" consisted of air, food and drink, motion and rest, sleep and waking, retentions and evacuations, and the passions of the mind. Although Bontekoe did not use the term "nonnaturals", the incomplete list of them in the Theetractaat closely resembles the standard list.

\footnotetext{
${ }^{40}$ Genesis 5.5.

${ }^{41}$ Bontekoe, 'Van de middelen', in Alle de philosophische ... werken, op. cit., note 5 above, vol. 2, p. 202.

${ }^{42}$ Bontekoe, Tractaat, op. cit., note 3 above, pp. 40-1.

${ }^{43}$ Ibid., p. 74: "Dat soo veele en dangereuse siecktens onststaan: ja de Lugt is de voornaamste die ons leven doet, maar wederom ' $t$ is de Lugt, die de principaalste Geessel is van den Rigter der Aarde, waar mede hy sijne Kinderen kastijd, en de Goddelosen straft: ja de Lugt is de beul die God meest gebruykt, om van d'Aarde weg te nemen, die de zelve niet meer waardig sijn".

${ }^{44}$ Ibid., pp. 45-6.
}

\footnotetext{
${ }^{45}$ Bontekoe, Gebruik en mis-bruik, op. cit., note 9 above, pp. 10-11.

${ }^{46}$ Bontekoe, Tractaat, op. cit., note 3 above, pp. 1-2, 3, 37, 53.

${ }^{47}$ Antoinette Emch-Dériaz, 'The non-naturals made easy', in Roy Porter (ed.), The popularization of medicine 1650-1850, London, Routledge, 1992, pp. 134-59, on p. 135.

${ }^{48}$ Ginnie Smith, 'Prescribing the rules of health: self-help and advice in the late eighteenth century', in Roy Porter (ed.), Patients and practitioners: lay perceptions of medicine in pre-industrial society, Cambridge University Press, 1985, pp. 249-82, on p. 250-1, 257.
} 
In the maintenance of life and health, air ranked first, followed by drink, food, exercise, sleep and rest, and, finally, the evacuation of excrements. ${ }^{49}$ The passions of the mind are not taken into account here, but they are covered in his 'Van de middelen', 50 showing that he took into consideration the Galenist list of the non-naturals, even though he arranged them differently and adapted them to his theories.

Bontekoe's physiology was based on that of his teacher Franciscus de le Boë Sylvius (1614-72), the English physician William Harvey (1578-1657) and the philosopher René Descartes (1596-1650). Bontekoe compared the human body with an organ: the body fluids flowed through the vessels like air through pipes. For the body to remain healthy, the fluids must flow through the vessels without impediment. Life and health depended on blood circulation, and this circulation on the thinness, moistness and warmth of the blood. ${ }^{51}$ If the blood became thick and slow, it could coagulate. During illness the blood flowed more slowly, which caused a wide range of diseases. ${ }^{52}$ If the blood had a "sharp" quality, it could corrode the vessels. ${ }^{53}$

Air was also essential for life, requiring continual inspiration, as any moment without it brought danger. Air kept the blood warm and thin. On the other hand, it could cause many serious diseases, epidemics or poisoning. ${ }^{54}$ The air was God's principal scourge for mankind. As judge of Heaven and Earth, he used it to castigate his children and punish the godless, ${ }^{55}$ destroying those not worthy of life. ${ }^{56}$ Ways of avoiding airborne disease were limited. It was possible to protect oneself against cold air, to avoid heat and damp by staying indoors, but if the air was polluted, you had to flee or improve it by art. Bontekoe's works discuss the correct foods and drinks at length. ${ }^{57}$ They were turned into a sap which supplemented and moistened the blood, cooled it, moderated its sharpness and made it thinner avoiding excessive thickness and dryness. Without food and drink, the blood would become sharp and thin, and it would be reduced through transpiration. ${ }^{58}$ Diet had an important effect on the blood. Bread, meat, eggs and milk were recommended because they made the blood warm and fluid. Sour fruit was harmful. ${ }^{59}$ The merits of tea fit nicely into Bontekoe's theories. Tea was a wonderful means of keeping the blood warm and thin. In the chapter in the Theetractat on the positive effects of tea on the kidneys and bladder, Bontekoe recounted that tea had cured him of the stone, using his own experience to give weight to his argument. ${ }^{60}$ As for the preparation of food, Bontekoe argued that past generations had been healthier. They ate simple, raw, unprepared food, which was perfectly healthy, whereas

\footnotetext{
${ }^{49}$ Bontekoe, Tractaat, op. cit., note 3 above, pp. $75-6$.

${ }^{50}$ Bontekoe, 'Van de middelen', in Alle de philosophische ... werken, op. cit., note 5 above, vol. 2 , pp. 199-276, on pp. 230-3.

${ }^{51}$ Bontekoe, Tractaat, op. cit., note 3 above, p. 65.

${ }^{52}$ Bontekoe, 'Van de siektens en de dood en hun verscheide manieren en oorsaken', in Alle de philosophische ... werken, op. cit., note 5 above, vol. 2 , pp. $138-98$, on p. 144.

${ }^{53}$ Ibid., pp. 138-45, Bontekoe outlines five general pathological states: breaking of vessels, blockage of vessels, not enough body fluids, the body fluids are too thick, too cold, too limy or clotted, and a sharp quality of the body fluids.
}

${ }^{54}$ Bontekoe, Tractaat, op. cit., note 3 above, pp. 64 , 73, 74, 76.

${ }^{55}$ See note 43 above.

${ }^{56}$ Bontekoe, Tractaat, op. cit., note 3 above, p. 74 .

${ }^{57}$ Bontekoe, 'Van de middelen', in Alle de philosophische ... werken, op. cit., note 5 above, vol. 2 , pp. 233-4, 216-30.

${ }^{58}$ Bontekoe, Tractaat, op. cit., note 3 above, p. 75.

${ }^{59}$ Bontekoe, 'Van de middelen', in Alle de philosophische ... werken, op. cit., note 5 above, vol. 2, pp. 219-21.

${ }^{60}$ Bontekoe, Tractaat, op. cit., note 3 above, pp. 81-2, 227. 


\section{Christoph Schweikardt}

cooking, frying, baking and brewing took away much of the best fluid contained in the foods. But over the centuries humans had become decadent, and it was impossible to recommend giving up cooked meals. Nevertheless, he insisted that the addition of more raw food to the diet would be beneficial in promoting a healthy and long life.

As regards motion and rest, Bontekoe considered work as part of the punishment for the fall of man. Hard physical work led to disease and death. The heavy work of sailors, peasants and labourers shortened their lives. The rich, on the other hand, gave themselves up to dancing, jumping, riding and hunting. Only very moderate exercise caused no harm. ${ }^{61}$ But dancing, the mother of wantonness and whoring, was unworthy of a Christian. ${ }^{62}$ Through exercise, the body fluids became thick, sharp and slow. Tiredness was a "little illness" resulting from motion, and sleep was its remedy. One should sleep for as long as one's body required it and no more. Just as a clock required winding, so the body, weakened by work, exercise and wakefulness, had to be restored by rest and sleep. Bontekoe passed over the retentions and evacuations in his 'Van de middelen', but dealt at length with the passions of the mind. Love, happiness and hope had positive effects. They kept the body fluids warm and encouraged their flow. Fear, fright, shame, anger, sadness, hate and envy made the body fluids sharp and thick, slowed their flow or made it irregular. ${ }^{63}$

The major part of his practical advice concerned foodstuffs including the new drugs tea and tobacco with their positive effects on health. Although, as in the Galenist tradition, Bontekoe saw moderation as essential in all activities, his theory departed somewhat from the older concept. He believed that a healthy person could eat as much as he or she wanted, provided the food was of good quality, and sleep for as long as desired without harmful consequences. ${ }^{64}$ Although serving as an advertisement for tea and tobacco, both the Theetractaat and 'Van de middelen' were appeals to the Christian duty to live according to moral principles and the rules of true medicine.

Bontekoe's scientific and moral reasoning is apparent not only in his concepts of the nonnaturals but also in his ideas on procreation and marriage. The debate on procreation in the second half of the seventeenth century was sparked by experimental investigations. ${ }^{65}$ The roles of the sperm cells, discovered in the 1670 s, and the egg were hotly debated. In 1651 , William Harvey postulated in his Exercitationes de generatione animalium that all that was alive came from the egg. ${ }^{66}$ In 1672, Reinier de Graaf (1641-73) published his De mulierum organis generationi inservientibus (The Generative Organs of Women), in which he assumed that the large egg-containing follicles in the ovary-now called Graafian follicles-which are as round as the egg but much larger, were the true mammalian eggs. This finding firmly established the theory that viviparous animals came from eggs. However, Antoni van Leeuwenhoek (1632-1723), who carried out microscopical research on sperm cells, believed that they were the sole carriers of primordial new lives. He was among the

\footnotetext{
${ }^{61}$ Bontekoe, 'Van de middelen', in Alle de philosophische ... werken, op. cit., note 5 above, vol. 2, pp. 207, 208, 209-10, 223-4.

${ }^{62}$ Bontekoe, 'Van de twyfelingen in de philosophie', in Alle de philosophische ... werken, op. cit., note 5 above, vol. 1, pp. 1-402, on pp. 56, 58 .

${ }^{63}$ Bontekoe, 'Van de middelen', in Alle de philosophische ... werken, op. cit., note 5 above, pp. $210-11,230$.
}

\footnotetext{
${ }^{64}$ Ibid., pp. 206, 211.

${ }^{65}$ Clara Pinto-Correia, The ovary of Eve: egg and sperm and preformation, University of Chicago Press, 1997; L W B Brockliss, 'The embryological revolution in the France of Louis XIV: the dominance of ideology', in G R Dunstan (ed.), The human embryo: Aristotle and the Arabic and European traditions, University of Exeter Press, 1990, pp. 158-86.

${ }^{66}$ Pinto-Correia, op. cit., note 65 above, p. 2.
} 


\section{More than just a Propagandist for Tea}

first who assumed that one animalcule, not many, was enough to bring about the new human being. 67

Laurence Brockliss describes what occurred between 1650 and 1675 as an "embryological revolution". ${ }^{68}$ A new generation of embryologists called for primacy of either the egg or the sperm instead of a two-seed theory inherited from the past. Hotly disputed was the closely connected question of whether embryologic development was based on epigenesis, gradual development and metamorphosis, or preformation, which meant that the foetus was pre-formed either in the egg or in the sperm before conception.

As shown by Brockliss, ideological constraint and theological imperatives were important for a specific theory to be accepted. This is also true for Bontekoe who made clear that spermatozoism was theologically unsound. In his chapter on procreation, 'Van de leden tot de Teeling geschapen', in his collected works he did not take sides on epigenesis or preformation, but argued as follows: Harvey showed that humans come forth from eggs. De Graaf and Swammerdam discovered that the ovary is an egg-nest. The male seed warms the eggs in the ovary. Leeuwenhoek's idea that there are living animals in the seed is strange. It is unbelievable that these living animals should be little children. Harvey proved by his experiments that most of the male seed is thrown out of the uterus after coitus. Many children would thereby get lost. It could not be believed that God, who punished the man who smeared his seed on the earth, would permit this. ${ }^{69}$ So the Theetractaat provided a splendid opportunity to remind its readers that they were dutybound to care for their offspring. The desire to have no children was godless-heathens, who lived in a world without God and hope, had reason to wish to be infertile, but not Christians. Whoring was criticized sharply, as well as waiting too long to get married, especially if the intention was to find a high ranking or wealthy spouse. This was sinful and a misuse of the body. ${ }^{70}$

\section{Positioning Bontekoe as an Enlightened Medical Reformer}

Bontekoe's publications offer a valuable insight into the world of a Dutch physician in the 1670 s who saw medical reform as a religious duty. He was not only an enthusiastic Cartesian but also-at least in his own view, if not in that of the Voetians-an orthodox Calvinist with no sympathy for Catholics, sectarian Christians or atheists. As we have seen, Bontekoe was not a tolerant man: for him sin was the prime cause of decay, illness, pain and death. In his career, however, religious matters are only one aspect in a complex interaction of personal, professional and philosophical issues which played a decisive role in a long sequence of controversies. Some points remain obscure, such as the allegations that he was in the pay of the United East India Company.

\footnotetext{
${ }^{67}$ Jan Swammerdam (1637-1680) also claimed to be the first discoverer. Ibid., pp. 43, 45, 70, 80 .

${ }^{68}$ Brockliss, op. cit., note 65 above, pp. $169,158$.

${ }^{69}$ Bontekoe, 'Van de leden tot de teeling geschapen', in Alle de philosophische ... werken, op. cit., note 5 above, vol. 1, pp. 79-84, on pp. 80-1. See Genesis 38: 4-10. God took Onan's life, because
}

when he slept with his brother's wife, he spilled his seed on the ground so as to not to raise up descendants for his brother, which was wicked according to the Lord. Pinto-Correia, op. cit., note 65 above, p. 80.

${ }^{70}$ Bontekoe, Tractaat, op. cit., note 3 above, pp. 106, 108-9, 112. 


\section{Christoph Schweikardt}

Born in $1647^{71}$ in Alkmaar, he trained in surgery before studying medicine at Leiden University from 1665 until 1667 . The son of Mennonite parents, he converted to the Reformed faith before receiving a medical doctorate in 1667 and getting married. ${ }^{72}$ Then he started to practise medicine in the town of his birth. After the death of his wife and two children, he was unable to pursue a successful career in the Netherlands. He fabricated his own medication and ran into quarrels with local apothecaries. When his unhappy second marriage ended in divorce, he moved to De Rijp. In 1674, he returned to Leiden University in order to attend the lectures of the Cartesian medical professor Theodor Craanen (1635-88) at a time of turmoil about the philosophy of René Descartes. Bontekoe fiercely defended Cartesian ideas and was finally banned from the university by the Curators in December 1675. Nevertheless he was enrolled again in 1676, which may signify that the main concern of the Curators was peace and order at the university rather than resisting Cartesian ideas, so Bontekoe was able to remain there. ${ }^{73}$ Then The Hague became the main centre of conflict until the early 1680s. Here, he brought out his Theetractaat, which included an 'Apology' abusing his conservative Galenist colleagues and condemning Galenist therapies such as bloodletting. Also, the two parts of his treatise Niew Gebouw van de Chirurgie of Heel-Kunst were published there in 1680 and $1681 .^{74}$ But the controversy with his colleagues may not have been his only reason for leaving The Hague. An anonymous book, published in 1680, now preserved in the Municipal Archive in The Hague, contains unpleasant gossip about him. It says that he styled himself as a martyr for Descartes and Coccejus. It also deals at length with his financial problems and his inability or unwillingness to pay his debts. ${ }^{75}$ If there is any truth in all this, his reputation in the Netherlands may have been severely damaged. From Amsterdam, his last residence in the Netherlands, his Notae provocatoriae of 1682 remain. ${ }^{76}$ They attack Gerard Blaes (Gerhardus Blasius, $c .1625-92$ ), medical professor at the illustrious school, the Athenaeum, in Amsterdam where Bontekoe and Blaes had disputed. ${ }^{77}$ Interestingly, the Notae

\footnotetext{
${ }^{71}$ Thijssen-Schoute convincingly argues against 1640 , op. cit., note 1 above, pp. 276-80.

${ }^{72}$ Martin Friedrich Seidel, Vitae eruditorum virorum, vol. 5, Historia librorum sive judicia accurata jucunda et utilia de variarum nationum ac facultatum scriptoribus, Berlin, 1682, Staatsbibliothek zu Berlin, Preussischer Kulturbesitz, Handschriftenabteilung, Ms. boruss. fol. 195, pp. 598-600, on p. 598.

${ }^{73}$ This is the conclusion of Thijssen-Schoute, op. cit., note 1 above, p. 283. There are various interpretations of this episode. Bontekoe gives his version in Tractaat, op. cit., note 3 above, pp. 359-67, where he maintains that the interdict of the Curators was not justified. The resolutions of the Curators are published in P C Molhuysen (ed.), Bronnen tot de geschiedenis der Leidsche Universiteit, part 3, 8 Febr. 1642-18 Febr. 1682, 's-Gravenhage, Martinus Nijhoff, 1918, pp. 283, 300-1, 314. Paul Dibon, 'Der Philosophieunterricht in den Niederlanden. B. Die Republik der Vereinigten Niederlande', in Schobinger, op. cit., note 10 above, pp. 42-70, on p. 58, emphasizes the pressure by the church authorities on the Curators. Dibon only mentions that the Curators withdrew
}

Bontekoe's permission to give private lectures.

${ }^{74}$ Cornelis Bontekoe, Niew gebouw van de chirurgie of heel-konst, 2 parts, 's-Gravenhage, Hagen, 1680-1681.

${ }^{75}$ Anonymous, Dialogue van een groote thee en tobacq suiper, over het wonderlijk hart gevecht voorgevallen in den Haag tusschen twee moedige hanen en schermers, Johan Fredericq Swetser, alias Doctor Helvetius, en Mennoniste Kees alias Dr. Cornelis Bontekoe, 1680, pp. 27-37.

${ }^{76}$ Cornelis Bontekoe, Notae provocatoriae in corollaria, quae disputationi suae de ictero opposuerat clariss. vir D. Gerardus Blasius, Amsterdam, Johannis ten Hoorn and Johannis Boumann, 1682.

${ }^{77}$ Harm Beukers, “ "Publycque lessen in de faculteyt van de medicina": Geneeskunde aan het Athenaeum illustre in de zeventiende eeuw', in E O G Haitsma Mulier, C L Heesakkers, P J Knegtmans, A J Kox en T J Veen (eds), Athenaeum illustre: elf studies over de Amsterdamse Doorluchtige School 1632-1877, Amsterdam University Press, 1997, pp. 311-30, on p. 324. 
provocatoriae are written in Latin, not Dutch. My impression is that Bontekoe had given up fighting publicly, but continued to defend his point of view within the profession. Bontekoe insisted that he, not his colleagues in The Hague and Amsterdam, was in the right and that Galen, whom he compared with his contemporaries, would not have rejected new discoveries simply because he had not found them in the Hippocratic or other ancient writings. ${ }^{78}$ So Bontekoe emigrated to Hamburg, before, finally, his life changed for the better. In 1683, he was appointed personal physician of the Great Elector Friedrich Wilhelm (1620-88) of Brandenburg-Prussia. ${ }^{79}$ Personal testimonies, such as one by a valet, were presented to the Prussian court, ${ }^{80}$ and certainly must have helped. In the same year, Bontekoe published a book stating that the 63rd year of life (Friedrich Wilhelm had been born in 1620) was no "moordjaar", a year with increased danger for life. ${ }^{81}$ Although the Elector favoured personnel of his own Reformed faith, for the appointment of personal physicians the medical qualification was probably more important. Among his personal physicians, Friedrich Wilhelm held Martin Weise senior (1605-93), a Lutheran, in highest esteem. ${ }^{82}$ Bontekoe's service was appreciated-he treated the Elector's gout successfully with large quantities of tea ${ }^{83}$ - however, it lasted only a short time. In 1685 , Bontekoe fell downstairs, fracturing his skull. Bloodletting was administered against his will, without reducing the flow of blood from his ear, and he died shortly afterwards. ${ }^{84}$

In her article on Bontekoe's fever treatise Reden over de koortzen, Johanna GeyerKordesch concludes that he was an enlightened reformer of medicine. One of her main points is that he waged a double battle, on the one hand against the fever theory of the "ancients", and on the other against the theories of contemporaries which he fought with arguments based on anatomy and chemistry, advocating experiment and observation. ${ }^{85}$

If the Enlightenment was, as Geyer-Kordesch defines it, a movement in which common sense swept away old irrational beliefs, the idea of autonomous reason was initiated and man's subsidiary position before God began to give way, ${ }^{86}$ then Bontekoe was not a forerunner of it, given his religious views. Roy Porter, however, made the point that the Enlightenment was, among other things, no crusade for atheism. ${ }^{87}$ So the question whether Bontekoe was an Enlightenment reformer is closely connected with the underlying concept of "Enlightenment", especially in the Dutch context. Here, different positions exist among

\footnotetext{
${ }^{78}$ Bontekoe, Notae provocatoriae, op. cit., note 76 above, p. 10.

${ }^{79}$ Johann Philipp Jacob, Elogia Brandenburgica sive illustrium Brandenburgi scriptorum ... vitae breviter commemoratae, Staatsbibliothek zu Berlin, Preussischer Kulturbesitz, Handschriftenabteilung, Ms. boruss. quart. 34, pp. 91-109, on p. 94.

${ }^{80}$ Seidel, op. cit., note 72 above, p. 598.

${ }^{81}$ Cornelis Bontekoe, Kort en vast bewys dat 'er geen annus climactericus of moort-jaar is, 's-Gravenhage, Pieter Hagen, 1683; Thijssen-Schoute, op. cit., note 1 above, p. 287.

${ }^{82}$ Peter Bahl, Der Hof des großen Kurfürsten: Studien zur höheren Amtsträgerschaft BrandenburgPreußens, Cologne, Böhlau, 2001, pp. 78, 206.

${ }^{83}$ Walter Artelt, Medizinische Wissenschaft und ärztliche Praxis im alten Berlin in Selbstzeugnissen: Ein Lesebuch, vol. 1, Von Elsholtz und Mentzel bis zum
}

Ausgang des 18. Jahrhunderts, Berlin, Urban and Schwarzenberg, 1948, p. 13.

${ }^{84}$ Thijssen-Schoute, op. cit., note 1 above, p. 288.

${ }^{85}$ Geyer-Kordesch, op. cit., note 12 above, pp. 1056; the full title of Bontekoe's fever treatise is: Reden over de koortzen; door welke aangewesen word, dat de gemene theorie en praktijk valsch, schadelijk en moordadig is, first published in 1681.

${ }^{86}$ These are parts of Johanna Geyer-Kordesch's definition of "Enlightenment" in the context of developments in eighteenth-century Germany: Johanna Geyer-Kordesch, 'Cultural habits of illness: the enlightened and the pious in eighteenth-century Germany', in Porter (ed.), op. cit., note 48 above, pp. 177-204, on p. 180.

${ }^{87}$ Roy Porter, Enlightenment: Britain and the creation of the modern world, London, Penguin Press, 2000, pp. 10-12. 


\section{Christoph Schweikardt}

Dutch scholars. One example is Rienk Vermij's doctoral thesis of 1991, a detailed study of a younger colleague of Bontekoe, the Purmerend town physician Bernard Nieuwentijt (1654-1718). Vermij shows how Nieuwentijt aimed at combining Calvinist religion with a scientific attitude in his Het regt gebruik der wereltbeschouwingen (The Right Use of Contemplating the World) in 1715. In Bontekoe's arguments, interesting parallels to those of his younger colleague can be found even if their views on the philosophical foundation of science-a Cartesian framework versus one based on English experimental philosophy-were distinct from each other. Nieuwentijt was also an orthodox Calvinist and explicitly expressed his belief that his religious and scientific views were in harmony with each other. In addition, he stated that God had cursed his creation, and defended a literal reading of the Bible. Vermij concludes that Nieuwentijt did not belong to the Enlightenment era, which is associated with tolerance, man as the centre of the world, a secular society, optimism, happiness, and a rejection of dogmatism, as well as the subordination of religion and revelation to rational principles. He saw a Dutch variant of the Enlightenment beginning in the second half of the eighteenth century after a caesura around $1750 .^{88}$

On the other hand, scholars such as Wiep van Bunge and Wijnand Mijnhardt date the beginning of the early Enlightenment in the Netherlands to around 1650 and 1660, respectively; ${ }^{89}$ thus it was well under way before Paul Hazard's "crise de la conscience européenne" started in the 1680s. ${ }^{90}$ Mijnhardt discusses the research of the last few decades, which has shown how the age of Enlightenment varied according to national traditions. This leads to the concept of a "Dutch Enlightenment" beginning, according to Mijnhardt, around the middle of the seventeenth century with the general debate on Cartesianism from 1660 onward. ${ }^{91}$ Mijnhardt's concept highlights the breach with Aristotelian philosophy, the importance of experimental research and the special Dutch way of finding a compromise between philosophy and theology (as well as between science and religion). If we accept this view of the Dutch Enlightenment, rather than Geyer-Kordesch's definition, Bontekoe definitely belongs to it.

\footnotetext{
${ }^{88}$ Vermij, op. cit., note 23 above, pp. 79-149.

${ }^{89}$ Wiep van Bunge, History of Philosophy in the Netherlands, http://www.eur.nl/fw/onderzoek/hisphil-neth.html (18.09.2001); Wijnand Mijnhardt, Nederland en de verlichting, Rekenschap Juni 1998, http://www.human.nl/rekenschap/juni1998/ nederland_verlichting.htm (13.09.2001).
}

\footnotetext{
${ }^{90}$ Paul Hazard, Die Krise des europäischen Geistes, La Crise de la conscience européenne, 1680-1715, mit einer Einfuihrung von Prof. Carlo Schmid, 5th ed., Hamburg, Hoffmann and Campe, 1965.

${ }^{91}$ Mijnhardt, op. cit., note 89 above.
} 